\title{
THE REVIEW OF SELECTED ELECTRICAL ENERGY STORAGE TECHNIQUES
}

\begin{abstract}
Aleksander Chudy
Lublin University of Technology

Abstract. The article contains basic information about selected mechanical, electrical and electrochemical techniques of electrical energy storage. Due to the rising popularity of renewable resources, electrical energy storage systems will play more and more significant role in the power engineering, electronics, car manufacturing and other key areas. This situation leads to the need to raise awareness of electrical energy storage.
\end{abstract}

Keywords: energy storage, batteries, flywheels, supercapacitors, superconducting magnetic energy

\section{PRZEGLĄD WYBRANYCH METOD MAGAZYNOWANIA ENERGII ELEKTRYCZNEJ}

Streszczenie. $W$ artykule zawarte zostaty informacje na temat obecnego stanu rozwoju wybranych metod mechanicznych, elektrycznych $i$ elektrochemicznych magazynowania energii elektrycznej. Ze względu na wzrost popularności odnawialnych źródel energii, magazynowanie energii elektrycznej będzie odgrywało coraz ważniejsza role $w$ elektroenergetyce, elektronice oraz innych kluczowych obszarach. Ta sytuacja prowadzi do potrzeby podnoszenia świadomości w zakresie magazynowania energii elektrycznej.

Słowa kluczowe: magazynowanie energii elektrycznej, baterie, koła zamachowe, superkondensatory, nadprzewodnikowe zasobniki energii

\section{Introduction}

The second half of the twentieth century in the context of electrical energy storage, EES, is primarily the construction of large-scale energy storage facilities (Pumped Hydroelectric Energy Storage, PHES), which were to help adjust the changing load to the permanent production of electricity from nuclear power plants. A new trend has emerged since the end of the 20th century - the development of renewable energy sources. From the classic centralized model, there is a visible movement towards the diffuse model, with a presence of so-called smart grids [12].

Renewable energy sources are known for power fluctuations due to changing weather conditions over time. The constantly growing share of variable and unstable electricity production from renewable sources is a serious challenge for power systems and motivation to improve and develop new methods of storing energy. Another reason for the development of energy storage systems is the aforementioned decentralization of electricity generation $[8,25]$.

This article provides an overview of selected methods for storing electric energy and presents the current state of development of these methods.

\section{Mechanical techniques of electrical energy storage}

Energy storage is typically a repetitive process with a large number of charging/discharging cycles. Contrary to classic electrochemical batteries, where the expected number of cycles is limited as a result of degradation phenomena, physical systems based on reversible mechanisms of different nature can be used at significantly longer life cycles. An example of such a system is a pumped storage power plant. This type of power plant can provide hundreds of megawatts. Other methods of electrical energy storage in the form of mechanical energy include Compressed Air Energy Storage, CAES and flywheels [18, 25].

\subsection{Pumped Hydroelectric Energy Storage}

Over $95 \%$ of the total installed power of energy storage systems comes from pumped storage power plants [6].

Pumped storage power plants are the most mature and the most available method for storing substantial amounts of energy. It serves to stabilize the electrical network by smoothing load peaks, load balancing, and frequency regulation. In combination with advanced power electronics, pumped storage power plants can also help in reducing the THD factor and can eliminate overvoltages and voltage drops [18].
A typical PHES power plant usually consists of an upper and a lower reservoir, a reversible turbine coupled to a generator/electric motor, which is usually a synchronous machine. This type of machine can be replaced by an asynchronous machine - DFIMG (doubly-fed induction motor generator) in modern variable speed systems. In such a case, an electronic converter does not operate at full power (only a fraction). Synchronous machine with a full-power designed converter can also serve as a solution for the variable-speed operation [25, 27].

Energy that can be stored by a pumped storage power plant can be described as the gravitational energy of water accumulated in the upper reservoir:

$$
\mathrm{E}=\mathrm{mgh}
$$

where $E$ - energy stored by a pumped storage power plant [J], $m$ - displaced mass $[\mathrm{kg}], \mathrm{g}-$ gravitational acceleration $\left[\mathrm{m} / \mathrm{s}^{2}\right]$, $h$ - the difference of the levels of both reservoirs [m] [18].

When the energy is cheap (off-peak hours), the pump pumps water to the upper tank and when energy is more expensive (peak demand hours), water from the upper tank is released and electricity is generated [18]. Fig. 1 shows a simplified diagram of the pumped storage power plant.

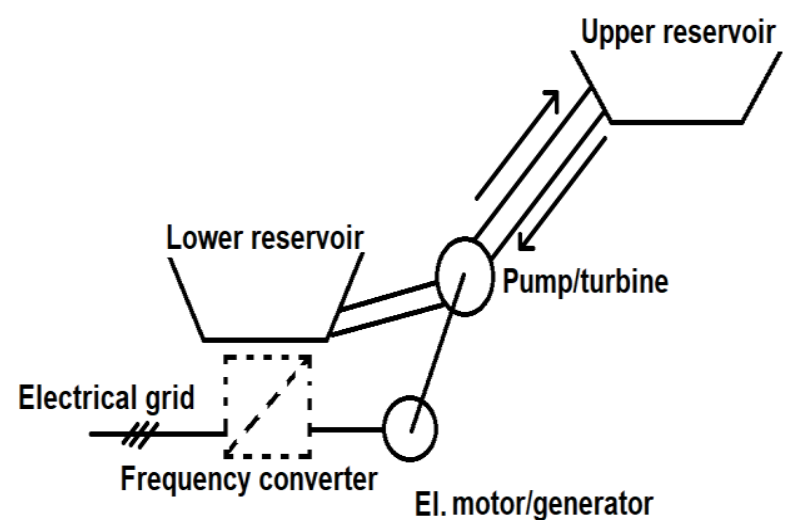

Fig. 1. Simplified diagram of the pumped storage power plant [25]

PHES power plant can store substantial amounts of energy with high reliability and low operating and maintenance costs. However, pumped storage power plants have several disadvantages. PHES power plant construction requires suitable area with a significant height difference between the two reservoirs and a substantial amount of water resources. Some projects of pumped storage power plants were cancelled because of their possible environmental impact. PHES construction sometimes is connected with creating a reservoir by damming 
a river and blocking the natural flow of water, which can disrupt the ecosystem, for instance by flooding previously dry areas [18].

The efficiency of pumped storage power plants varies between $60-80 \%$. A large discrepancy is a result of the maturity of this technology [18].

The leader in the amount of the total installed power coming from PHES is Japan (over $27 \mathrm{GW}$ ) with China and the USA in the following places. The total installed power in Poland is $1745 \mathrm{MW}$, most of which comes from the Żarnowiec Pumped Storage Power Plant (716 MW) [18, 34].

\subsection{Compressed Air Energy Storage}

Compressed air energy storage, CAES, refers to a method of energy storage as a potential energy of compressed air. It is the second (after pumped storage power plants) commercially available method of large-scale storage of electricity. It is a combination of natural geological formations with a technology created by man. It allows the reception, storage and transmission of energy through a series of thermodynamic cycles. The method of energy storage using compressed air was patented in the United States in 1948 for the very first time. Currently, CAES has many applications, for instance in industry and transport [8, 18, 32].

The CAES system consists of underground and above-ground elements. We can distinguish: a motor/generator, an air compressor, a turbine train, control devices, auxiliary equipment and an underground component - a cavity, called also a cavern, a reservoir, which can be formed from three different types of geological formations (underground rock chambers, salt caverns, porous media reservoirs) [8]. Fig. 2 shows a general scheme of CAES.

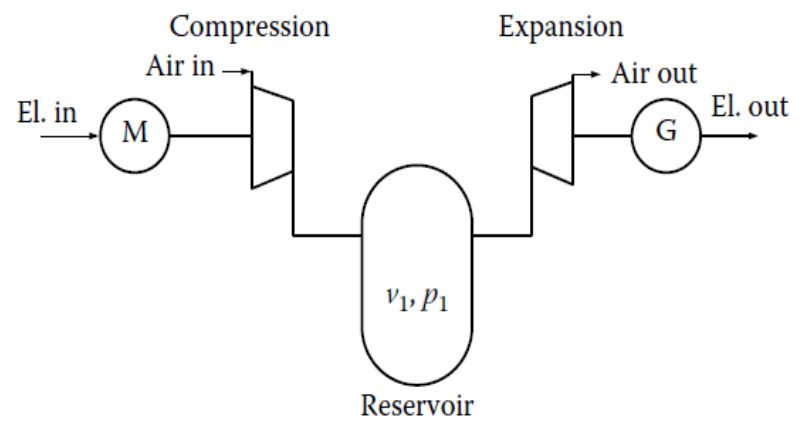

Fig. 2. A general scheme of CAES ( $M$ - a motor, $G$ - a generator) [25]

The amount of energy stored in the cavern (full expansion under isothermal conditions) can be described as:

$$
E_{C A E S}={ }_{P_{1} V_{I}}\left[\begin{array}{c}
\ln \frac{P_{1}}{P_{a}}-1+\frac{P_{1}}{P_{a}}
\end{array}\right]
$$

where $P_{l}$ is a pressure in the cavern [Pa], $V_{l}$ is a volume of the cavern $\left[\mathrm{m}^{3}\right]$, and $P_{a}$ is a pressure of the surrounding [Pa] [25].

In the compressed air method of energy storage, we can distinguish two main stages - compression and expansion of air.

There are two main types of CAES: diabetic and Advanced Adiabatic Compressed Air Energy Storage, AA-CAES [32].

The air compression process usually takes place when energy is cheap. An electric machine participates in it as a motor. It drives the compression machine and the air is transported to the cavern [32]. In a case of the diabatic CAES, the heat generated as a result of the air compression is not stored. The heat is sent to the environment. When there is a greater demand for energy, the air is released to the environment and it is used to burn the natural gas. The fumes reach the two-stage turbine, which expands them and generates electricity. The expanded air must have the appropriate temperature to compensate for the energy losses from the previous cooling process and to prevent the turbine from icing. The round-trip efficiency of the diabetic CAES power plant ranges from $42 \%$ to $54 \%[8,18]$. There are only two diabatic
CAES power plants on the world. They are located in Huntorf in Germany and in McIntosh in the USA. The first one is completely automated. Their power and efficiencies are $321 \mathrm{MW}(42 \%)$ and 110 MW (54\%) respectively. Higher efficiency of the McIntosh power plant is a result of a heat exchanger utilization $[8,18,21,32]$.

In AA-CAES, the heat from compression is stored so that it can be used to warm up the air leaving the cavern. This method is free of combustion gases and its efficiency is estimated at around $70 \%$. The AA-CAES is distinguished by one- or multi-stage systems. In the first group of systems, air compression occurs in one stage, and indirect cooling does not take place. In multi-stage CAES, compression and decompression are divided into several stages, which causes slight temperature to increase at each stage and operation of the heat exchanger. Advanced adiabatic CAES is currently in the research phase. The most important AA-CAES project is a German project ADELE, which aims to develop elements of the system that would allow the construction of a power plant $[8,18,26]$.

The development of CAES is connected with various ideas. One of those ideas was to put a water column into the cavern so that it would maintain a constant pressure. This is reflected in another solution - Underwater CAES, UW-CAES. The marine environment has the potential to provide ideal conditions for storing compressed air. The absence of an underground tank greatly reduces the cost of UW-CAES which is a great advantage. Instead of the underground tank, a tank that is placed in water is used. This tank is named as an energy bag. The idea of such a system is to use the surrounding hydrostatic pressure to equalize the pressure of the stored air. The tank function is reduced to provide the boundary between air and water. Strong anchoring of such a tank is crucial due to the Archimedes law $[8,18,25]$. Fig. 3. shows the concept of the UW-CAES (the compression/expansion station located on the shore and compressed air is supplied to the tank through the pipe).

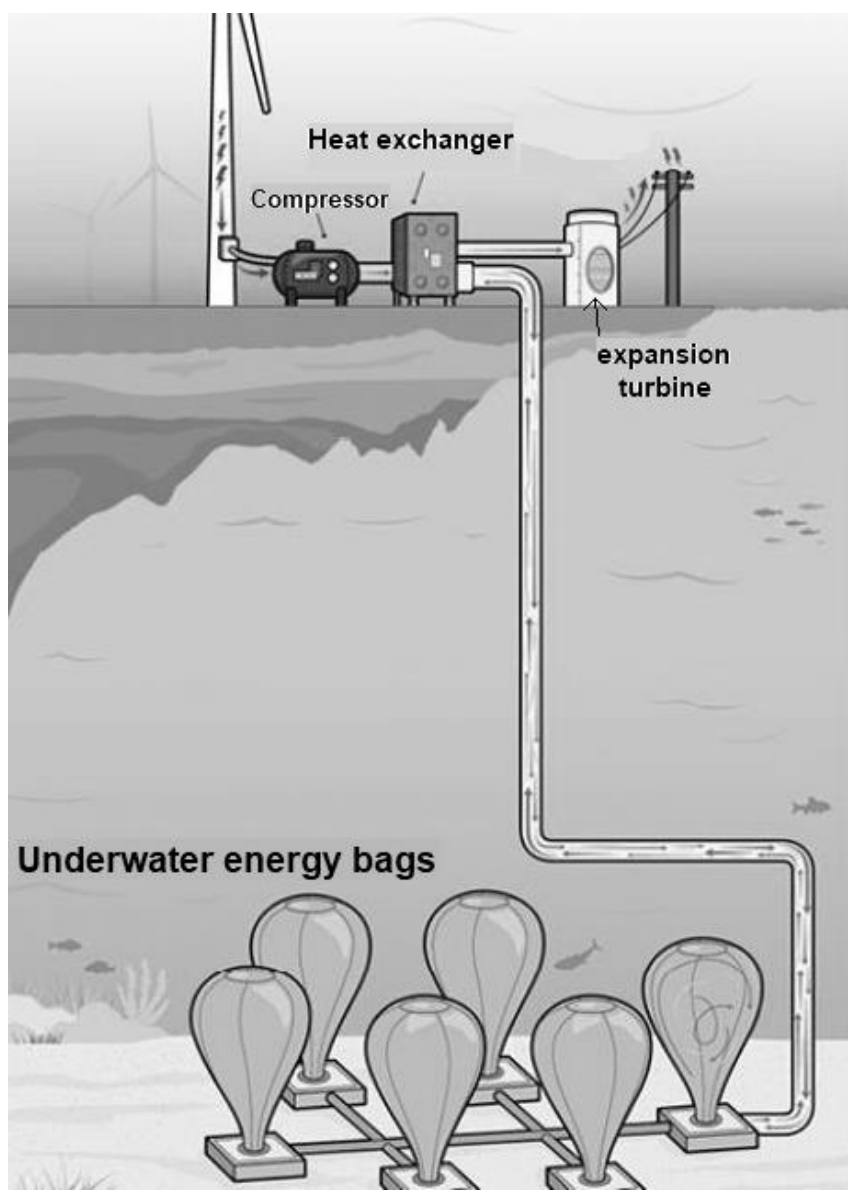

Fig. 3. Underwater Compressed Air Energy Storage concept [35] 
Underwater Compressed Air Energy Storage is currently in the research and development phase. There are problems with the placement of tanks at the bottom of the seas, oceans and lakes, as well as problems with the tightness of the tanks themselves and the pressure drop. Round-trip efficiency of currently tested UW-CAES systems is similar to conventional CAES round-trip efficiencies. It is estimated that in the future their round-trip efficiency will exceed $80 \%$ [18].

\subsection{Flywheel energy storage systems}

Flywheels are able to store the electrical energy in a kinetic energy form. This energy is proportional to the moment of inertia and the square of the angular velocity of the flywheel as it is shown in the following equation [1] :

$$
E_{k}=\frac{1}{2} I \omega^{2}
$$

where $E_{k}$ - energy stored in a flywheel [J], $I$ - moment of inertia $\left[\mathrm{kg} / \mathrm{m}^{-2}\right], \omega-$ angular velocity $[\mathrm{rad} / \mathrm{s}]$.

It can be concluded that the higher the angular velocity and the moment of inertia is, the more energy can be stored [21].

Two types of flywheels can be distinguished: low-speed flywheels (5000-10000 rpm) and high-speed flywheels $\left(10^{5} \mathrm{rpm}\right)$ $[8,21]$. The higher the angular velocity, the smaller the radius of the rotating body must be. Materials must also withstand centrifugal forces. Therefore, for high rotational speeds, anisotropic materials such as carbon fiber laminates or glass fiber reinforced plastics are used. Rotating masses that have medium angular speeds and that are made of cheap materials are typically used in a low cost systems [21].

Flywheels have many shapes. The most popular option is a disk-shaped flywheel that is subjected to equal forces [25]. The shape of the flywheel have an effect on mass and volume densities of power and energy [8].

The typical flywheel electric energy storage system includes: a flywheel, group of bearings (mechanical or magnetic), a generator/motor, a control and power conditioning system (C-PCS), vacuum housing [8,9]. Fig. 4. presents flywheel energy storage system.

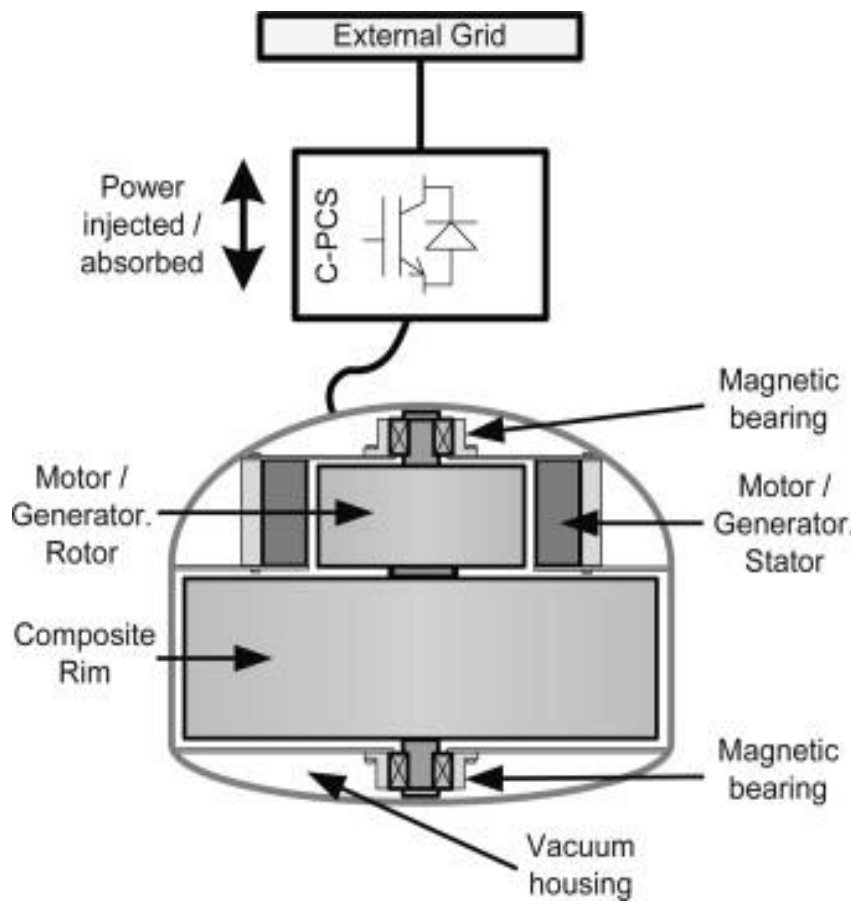

Fig. 4. Flywheel energy storage system [9]

During charging, the motor is used to accelerate the rotating mass (flywheel). The state of charge of such a system reflects the number of revolutions per minute. A vacuum and magnetic bearings are used in such a way that the resistance to rotational motion is as low as possible. During discharge, the generator is driven by the inertia of the flywheel, which reduces the angular velocity of the rotating mass $[8,21]$.

Flywheel energy storage systems have numerous advantages. They are characterized by a large number of charge/discharge cycles, high round-trip efficiency (80-95\%) and short deployment time (15 ms) [21].

An important drawback of flywheel energy storage systems is that they can be dangerous. If the flywheel becomes unbalanced or starts to fall apart, parts of the flywheel can obtain high velocities. For this reason, flywheels usually consist of small parts. Flywheels are usually placed in a very durable steel housing, and large units are placed underground for safety reasons [15]. It seems that currently there are not many documents touching on the subject of flywheel safety standards. The document of the US Department of Energy representative from 2015 is noteworthy. Issues related to the design and operation of flywheels were discussed in this paper [3]. Another disadvantage of flywheel energy storage systems is their self-discharge time - more than $50 \%$ of energy is lost after 5-10 hours from full charge [21].

Applications of flywheel energy storage systems include:

- astronautics - flywheels are used for position control, momentum management or as a main or auxiliary energy storage system for spacecrafts and satellites [11],

- transport - traction, electric and hybrid cars. This contributes to reducing environmental pollution and fuel consumption [8]. Flywheels absorb energy during the recuperation braking phases and release it during acceleration [21],

- Uninterruptible Power Supplies - high power flywheels are most often used as a short-term energy storage device, so that there is no complete loss of power from the grid when other types energy storage devices have not provided their stored energy yet (slower response) - cooperation of flywheels with batteries,

- supporting renewable sources - frequency regulation (power fluctuations) [5].

The costs of flywheel energy storage systems depend mainly on the demand for power and energy, which can significantly vary. It can be concluded that power electronic converters have opened the way for flywheels in applications for the storage of electricity. Currently, two ways of developing this method of energy storage can be noticed: light flywheels with high angular velocities and large mass flywheels [21].

\section{Mechanical techniques of energy storage}

\subsection{Electrochemical Capacitors}

Electrochemical capacitors, EC, are named in various ways due to the lack of uniform terminology. Manufacturers name them as ultracapacitors, power capacitors, golden capacitors or supercapacitors. Usually various types of EC operate differently. However, their common feature is an extraordinary high capacitance of these devices [2]. One of the biggest advantages of electrochemical capacitors is that they can be charged or discharged very quickly [8].

There are three types of electrochemical capacitors taking into account the mechanism of the storage of a charge and the type of an active material:

- Electric Double Layer Capacitors (EDLCs). This type of supercapacitor is the most popular on the market. In EDLCs liquid electrolyte is utilized and their electrodes are made of active carbon with a large active surface,

- pseudo-supercapacitors. This type of electrochemical capacitor is not as much popular as the previous one. Only a few companies use pseudo-supercapacitors. Due to the fact that in this element redox reactions occur, pseudo-supercapacitors are closer to batteries than to capacitors,

- hybrid supercapacitors, they are the most advanced technologically compared to two previous capacitor types. They are in a research phase. The main advantage of hybrid supercapaci- 
tors is the possibility of providing high currents and high energy density. These elements are similar to Li-ion batteries, if construction and operation is considered [19].

Due to the fact that the supercapacitor consists of two electrodes usually made of porous activated carbon, which has a large active surface, its capacity is much larger than classic capacitors [25]. It can be concluded from the following equation:

$$
C=\frac{\varepsilon_{\mathrm{O}} \varepsilon_{r} S}{d}
$$

where $C$ - the capacitance of the capacitor $[\mathrm{F}], \varepsilon_{0}-$ the vacuum permittivity $[\mathrm{F} / \mathrm{m}], \varepsilon_{r}-$ the relative permittivity, $S-$ the area of overlap of the two plates $\left[\mathrm{m}^{2}\right], d$ - the separation between the plates [m] [31].

In 1957, Howard Becker patented the very first double-layer capacitor with an extremely large capacity [30]. It was designed for low voltage operation. Electrodes of this capacitor were made of carbon material. In 1978, Nippon Electric Company presented the first electrochemical double-layer capacitor, which achieved a commercial success. It was also the very first time when the term supercapacitor appeared. In the 1990s, the United States began spending more and more money on the development of supercapacitors, which resulted in the improvement of this technology - capacitors with energy densities of around $2 \mathrm{Wh} / \mathrm{kg}$ appeared. The beginning of the 21 st century was connected with capacitors that had energy densities of $3.5 \mathrm{Wh} / \mathrm{kg} 4.9 \mathrm{Wh} / \mathrm{kg}$ [21].

Two electrodes and an electrolyte (a solid or a solution) between them creates a supercapacitor. Conducting ions and separating the positive electrode from the negative electrode are two main functions of solid state electrolytes. If electrolytes are in a liquid state, an inert porous separator allows the ions to go through to form a conducting current [31].

Putting two electrodes, for instance carbon rods, into a baker with an electrolyte (salt water) in it results in a construction of an elementary electric double layer capacitor. During charging anions move towards positive electrode and cations move towards negative electrode. Thus, the creation of two electric double layers. A potential difference between two electrodes comes from a separation of ions $[8,20]$. Fig. 5. presents an electric doublelayer capacitor consisting of two conductors inserted in a beaker which contains an electrolyte

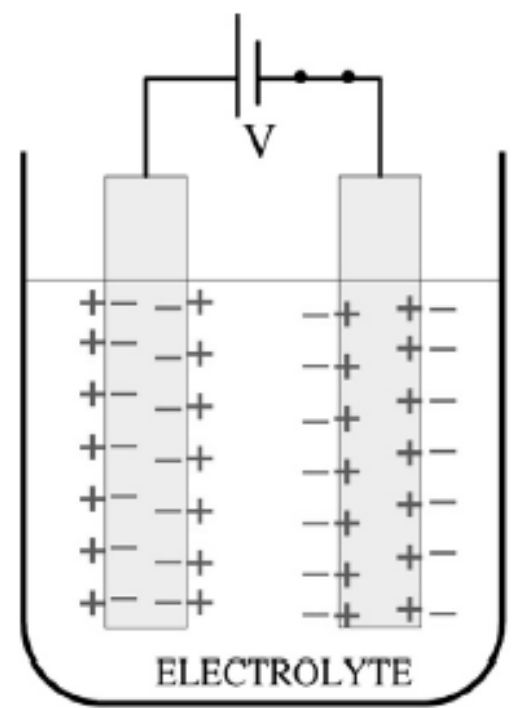

Fig. 5. Electric double-layer capacitor consisting of two conductors inserted in a beaker which contains an electrolyte [20]

Electrodes are a very important element of a supercapacitor. The density of energy and power of an electrochemical capacitor and its final capacity depend on the material from which they are made. Electroactive materials used to make electrodes of electrochemical capacitors are divided into two categories: active carbon materials and pseudo-active (metal oxide) materials.
Carbon has many advantages that allow it to be used in the field of energy storage: lower cost compared to pseudo-active materials, wide availability, temperature stability, corrosion resistance and high conductivity.

Electrolytes used in supercapacitors can be divided into two groups - aprotic and protic. Each of these groups has their advantages and disadvantages. Water-based protic solvents are friendlier for environment, securer and provide higher conductivity. Aprotic electrolytes have a greater range of operating voltages compared to a water-soluble electrolyte, which results in higher energy density [19].

When there is a need to release a huge amount of energy in a very short time, supercapacitors are one of the best choices. These elements are used in personal computers and Uninterruptible Power Supplies (UPS). They can also store energy from renewable resources. The main application field of supercapacitors is an automotive industry. Nowadays, these types of capacitors are mainly used in hybrid electric vehicles, electric vehicles, for instance trains and trolleybuses. In today's hybrid vehicles, the engine is usually turned off completely when the vehicle is stopped and when hybrid electric vehicle needs to start, it uses energy stored in supercapacitors. This is known as a start-stop system. A replacement of a lead-acid battery with a higher capacity with one that has a lower capacity connected to a supercapacitor is more and more popular among car manufacturers [19].

The maximum voltage of supercapacitor is about $2.85 \mathrm{~V}$. It is predicted that this voltage will increase as a result of further development and research $[8,21]$. Electrochemical capacitors can operate at temperatures ranging from $-20^{\circ} \mathrm{C}$ to $65^{\circ} \mathrm{C}$. One of the major disadvantages of electrochemical capacitors is their price. It is a result of still low popularity and immaturity of this technology. Problems with durability, limited performance and low voltage occur. In 2013, cost of a single supercapacitor with a capacity of $50 \mathrm{~F}$ was $6.9 €$ per piece $[2,21]$.

High power density is not the only one advantage of supercapacitors. They have short charging times and longer life cycles compared to conventional batteries (millions of charging/discharging cycles), long shelf life and high round-trip efficiency. They can also be fully charged or discharged without affecting their lifetime. Storing energy by supercapacitor is still a developing technology and it will be necessary to establish uniform terminology and classification of these elements in the future [2].

\subsection{Superconducting magnetic energy storage}

The very first superconducting magnetic energy storage, SMES, was constructed in the 1970s in the United States [16].

A superconducting coil, a power conditioning subsystem and cooling and vacuum subsystems are basic elements of SMES. The wire from which the superconducting coil is made is usually $4 \mathrm{~mm}$ wide. It consists of five layers:

- an epoxy resin insulation,

- a stabilizer - made of copper or silver,

- a superconducting substrate - produced from a rare earth metal,

- a buffer layer - made of alumina,

- a metal substrate $[4,9]$.

Fig. 6 presents a general scheme of the superconducting magnetic energy storage system.

The amount of the electrical energy stored in a superconducting coil in the form of magnetic field is shown in the following equation [10]:

$$
E_{S M E S}=\frac{1}{2} L^{2}
$$

where $E_{S M E S}$ - the amount of the stored energy in the superconducting coil $[\mathrm{J}], L-$ the inductance of the coil $[\mathrm{H}]$, $i$ - direct current flowing through the coil [A]. 


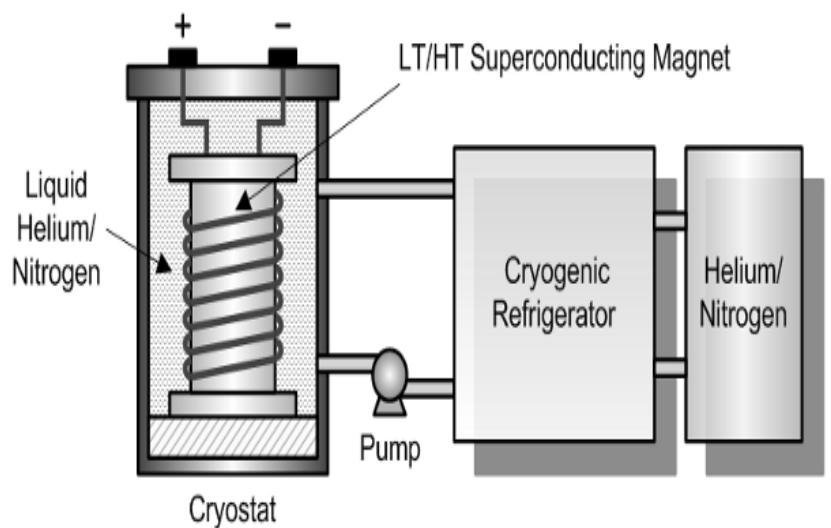

Fig. 6. Superconducting Magnetic Energy Storage system [33]

High current is required to store substantial amounts of energy. Since the losses in the electric wires are dependent on the square of the current value, it is crucial to obtain the lowest possible resistance. Therefore, the coils are made of superconducting materials. A state in which the resistance is zero is called superconductivity. This is a result of quantum effects. Superconductivity is typically achieved at very low temperatures. Coils of SMES are cooled cryogenically to achieve a temperature lower than critical for a given material. During charging, the superconducting coil is supplied with DC current from the inverter. The electric current induces a permanent magnetic field in which energy is accumulated. To be able to use the superconducting properties of the coil, it must be placed in liquid helium to guarantee a temperature below $260^{\circ} \mathrm{C}$ or in liquid nitrogen, so as to obtain a temperature below $196^{\circ} \mathrm{C}$. An example of a material from which a superconducting coil can be made is niobium, which requires a temperature below $9.25 \mathrm{~K}$. This can be achieved by liquid helium cooling. Other materials, such as high temperature ceramic superconductors, have a critical temperature in the range of $35-138 \mathrm{~K}$. They allow cooling with cheaper materials similar to liquid nitrogen (for materials with a critical temperature above $77 \mathrm{~K}$ ). Current and energy stemming from magnetic field are reduced during discharge [9, 16, 21, 23].

SMES systems are short-term energy storage devices that can provide a large amount of energy in a short time like supercapacitors. Superconducting magnetic energy storage is used to improve the power factor, the stability of the power system, an automatic generation control, stability of wind generators. The disadvantages of SMES include: large losses associated with the cooling process (this is the main area of research associated with this method of energy storage), difficulties in production and maintenance, a large price. Depending on the application of the SMES system, different cooling systems are distinguished $[8,9,21,23,24]$

The forecasts for the future of superconducting magnetic energy storage vary significantly. Some experts in the topic of energy storage argue that SMES will not be widely used, while others say that superconducting magnetic energy storage can become more popular due to the future improvements of SMES properties. Undoubtedly, the discovery of a material that would provide superconductivity at room temperature would lead to a major breakthrough in the field of energy storage. At present, it must be concluded that such material does not exist $[8,9,21]$.

\section{Redox Flow Batteries}

The very first redox flow battery (RFB) system was demonstrated by NASA in the 1970s. Iron and chromium were used in this system. The battery was not highly efficient due to a problem with cross-contamination of electrolytes. Flow batteries can be considered as one of types of fuel cells (the possibility of generating electricity during continuous fuel supply and a similar structure for fuel cells with a protonexchange membrane, PEM) $[8,13]$.
The characteristic elements of flow batteries are two electrodes, an ion-exchange membrane, pumps and two tanks in which electrolytes (anolyte and catholyte) are kept separately. The electrolytes are pumped from separate reservoirs to the reactor, which consists of the previously mentioned electrodes and the membrane. The tasks of the membrane are preventing mixing of the electrolytes mixing and transporting charged ions. The operation of such an energy storage technique is based on redox reactions [8, 13, 14, 25]. Fig. 7 shows a general scheme of a redox flow battery.

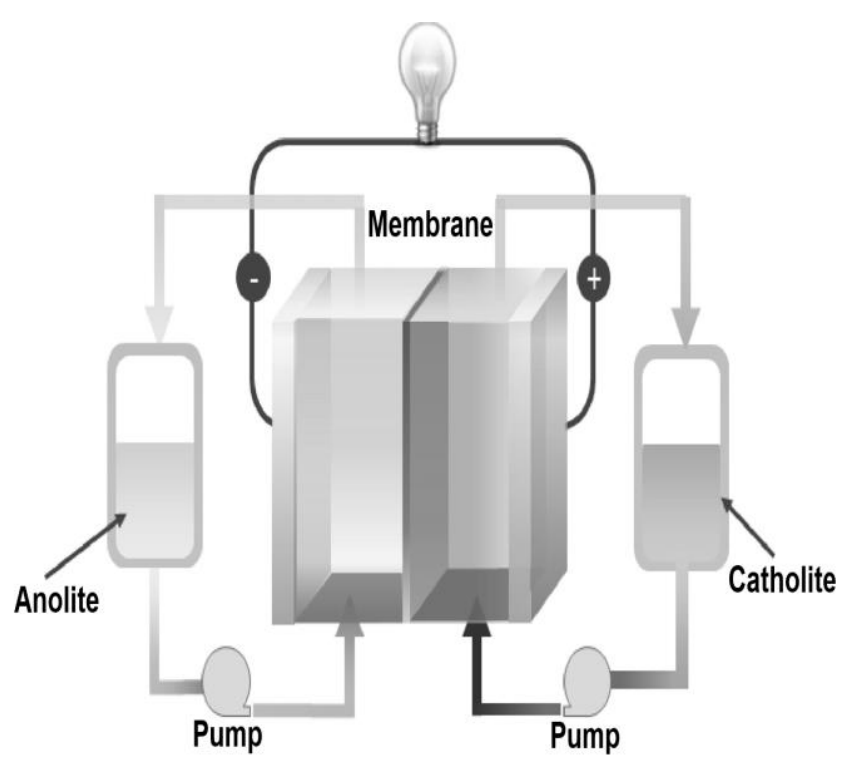

Fig. 7. General scheme of a redox flow battery [7]

The major advantages of redox flow batteries are:

- scalability - the amount of the stored energy depends on the volume of the electrolytes in the tanks. The power of a redox flow battery depends on the surface area of the membrane at which the redox reactions occur. The more cell stacks, the higher the power [25, 28],

- over 200,000 charging/discharging cycles in some demonstration systems [21],

- high level of safety - most electrolytes used in redox flow batteries are non-flammable [8,29],

- fully discharge is not harmful [13, 14].

Manufacturers and researchers of flow batteries create systems that use various elements as electrolytes, for example: iron and chromium, bromine and polysulfide, zinc and bromine as well as vanadium [8].

Vanadium is currently the most popular and the greatest hopes are bound with vanadium redox flow batteries, VRFB. Several generations of this kind of flow batteries have been created. One VRFB cell can reach a voltage of $1.3 \mathrm{~V}$, the mass density is between 25 and $40 \mathrm{Wh} / \mathrm{kg}$, and round-trip efficiency of VRFB reaches up to $80 \%[17,21]$.

As with all innovative technologies, researchers and manufacturers of flow batteries must meet the requirements that would allow the commercial use of this method of energy storage. At this point it is difficult to say which type of flow battery is the best or will be the best in the future. Undoubtedly, there is a need to support this technology through further industrial and academic research as well as various subsidies. Redox flow battery is a very promising method of energy storage due to the scalability. Commercial success of RFB might be possible with government incentives and well-thought-out business models $[14,25]$.

Redox flow batteries might become successful if their profitability is demonstrated. Membrane materials are currently expensive and tend to be polluted and degraded. One of the most popular membranes (Nafion) used in aqueous flow batteries has high proton conductivity and stability, but there is a reactant 
crossover problem. The constant growth of the popularity of anion-exchange membranes used in non-aqueous flow batteries can also be observed, however, they are problematic due to the fact they do not cope with the sharp edges of crystalline metal ions. There are also several studies being carried out on a subject of a flow battery without an ion-exchange membrane. This would result in a significant reduction in the cost of flow batteries, because the electrolyte accounts for up to $90 \%$ of the total flow battery cost $[8,22]$.

\section{Conclusions}

Electrical energy storage includes a number of technologies with varied technical possibilities and scalability. Due to this fact, EES is widely used in power engineering, industry and many other areas. It should be borne in mind that the further development of automation technology is one of the pillars of the development and success of electrical energy storage.

Although pumped storage power plants have been in use for a few decades, interest in other, less mature, innovative energy storage techniques is growing very quickly due to their favorable properties. Supercapacitors and SMES can transfer a large amount of energy to the grid in a short time, and flow batteries are known for their outstanding scalability properties [12].

The benefits of energy storage are: improvement of power quality and the efficiency of an energy system, increased usage of renewable sources, growth in self-consumption and self-production of energy, increased access to energy, which is partially the result of off-grid electrification, improvement of stability, reliability and resilience of the electrical grid [12].

\section{References}

[1] Amiryar M. E., Pullen K. R.: A Review of Flywheel Energy Storage System Technologies and Their Applications. Applied Sciences 7(3)/2017, 286, [DOI: 10.3390/app7030286].

[2] Béguin F.: Supercapacitors. Wiley-VCH, Weinheim 2013

[3] Bender D. A.: Recommended Practices for the Safe Design and Operation of Flywheels, 2015.

[4] Boicea V. A.: Energy Storage Technologies: The Past and the Present. Proc. IEEE 102(11)/2014, 1777-1794, [DOI: 10.1109/JPROC.2014.2359545].

[5] Bolund B., Bernhoff H., Leijon M.: Flywheel energy and power storage systems Renewable and Sustainable Energy Reviews, 11(2), 2007, 235-258.

[6] Chang L.: Review on Distributed Energy Storage Systems for Utility Applications. CPSS Transactions on Power Electronics and Applications 2(4), 2017, 267-276. [DOI: 10.24295/CPSSTPEA.2017.00025].

[7] Chen H., Cong G., Lu Y.-C.: Recent progress in organic redox flow batteries: Active materials, electrolytes and membranes. Journal of Energy Chemistry 27(5)/2018, 1304-1325, [DOI: 10.1016/j.jechem.2018.02.009].

[8] Chudy A.: Nowoczesne technologie magazynowania energii elektrycznej. Praca magisterska, Katedra Sieci Elektrycznych i Zabezpieczeń, Politechnika Lubelska, Lublin 2018.

[9] Díaz-González F., Sumper A., Gomis-Bellmunt O., Villafáfila-Robles R.: A review of energy storage technologies for wind power applications. Renewable and Sustainable Energy Reviews 16(4)/2012, 2154-2171, [DOI: 10.1016/j.rser.2012.01.029].

[10] Farhadi M., Mohammed O.: Energy Storage Technologies for High-Power Applications. IEEE Transactions on Industry Applications 52(3)/2016, 19531961, [DOI:10.1109/TIA.2015.2511096].

[11] Gaede J., Rowlands I. H.: How 'transformative' is energy storage?: Insights from stakeholder perceptions in Ontario. Energy Research \& Social Science 44/2018, 268-277, [DOI:10.1016/j.erss.2018.05.030].
[12] Hiksas M. M., Aninditio M. L.: Redox Flow Batteries for small scale energy storage. 2016 IEEE Conference on Technologies for Sustainability (SusTech), 2016, 134-139, [DOI:10.1109/SusTech.2016.7897155].

[13] Hu X., Zou C., Zhang C., Li Y.: Technological Developments in Batteries: A Survey of Principal Roles, Types, and Management Needs. IEEE Power and Energy Magazine 15(5)/2017, 20-31, [DOI:10.1109/MPE.2017.2708812].

[14] Huggins R. A.: Energy storage. Springer 2016.

[15] Janowski T.: Nadprzewodnikowe zasobniki energii. Liber Duo, Lublin 2007.

[16] Jarnut M., Wermiński S., Kaniewski J., Waśkowicz B.: Properties of smallscalle flow battery for prosumer-owned microgrid. IECON 2016 - 42nd Annual Conference of the IEEE Industrial Electronics Society, 2016, 6566-6571, [DOI:10.1109/IECON.2016.7794008].

[17] Letcher T. M.: Storing energy with special reference to renewable energy sources. Elsevier, Amsterdam 2016.

[18] Libich J., Máca J., Vondrák J., Čech O., Sedlaříková M.: Supercapacitors: Properties and applications. Journal of Energy Storage 17/2018, 224-227, [DOI:10.1016/j.est.2018.03.012].

[19] Luo X., Wang J., Dooner M., Clarke J.: Overview of current development in electrical energy storage technologies and the application potential in power system operation. Applied Energy 137/2015, 511-536, [DOI: 10.1016/j.apenergy.2014.09.081].

[20] Miller J. R.: Perspective on electrochemical capacitor energy storage. Applied Surface Science 460/2017, 3-7, [DOI: 10.1016/j.apsusc.2017.10.018]

[21] Moseley P. T., Garche J.: Electrochemical energy storage for renewable sources and grid balancing. Elsevier, Amsterdam 2015.

[22] Mousavi G. S. M., Faraji F., Majazi A., Al-Haddad K.: A comprehensive review of Flywheel Energy Storage System technology. Renewable and Sustainable Energy Reviews 67/2017, 477-490, [DOI:10.1016/j.rser.2016.09.060].

[23] Musbaudeen O. B., Saif A., Hong S.: Prospects of recently developed membraneless cell designs for redox flow batteries. Renewable and Sustainable Energy Reviews 70/2017, 506-518, [DOI: 10.1016/j.rser.2016.11.234].

[24] Peña-Alzola R., Sebastián R., Quesada J., Colmenar A.: Review of flywheel based energy storage systems. 2011 International Conference on Power Engineering, Energy and Electrical Drives, 1-6, 2011 , [DOI: 10.1109/PowerEng.2011.6036455].

[25] Rufer A.: Energy storage. CRC Press, Taylor \& Francis Group, Boca Raton 2018.

[26] RWE Power: ADELE Adiabatic Compressed-Air Energy Storage for Electricity Supply. RWE Power AG, Essen/Koln 2010.

[27] Schlunegger H.: Pumping efficiency-A $100 \mathrm{MW}$ converter for the Grimsel 2 pumped storage plant, 2014. [04.10.2018].

[28] Weber A. Z., Mench M. M., Meyers J. P., Ross P. N., Gostick J. T., Liu Q. Redox flow batteries. A review Journal of Applied Electrochemistry 41(10)/2011, 1137, [DOI: 10.1007/s10800-011-0348-2].

[29] Whitehead A. H., Rabbow T. J., Trampert M., Pokorny P.: Critical safety features of the vanadium redox flow battery. Journal of Power Sources 351/2017, 1-7, [DOI: 10.1016/j.jpowsour.2017.03.075].

[30] Yan J.: Handbook of Clean Energy Systems. John Wiley \& Sons, Ltd, Chichester 2015.

[31] Yu A.: Electrochemical supercapacitors for energy storage and delivery. Taylor \& Francis, Boca Raton 2013.

[32] Zohuri B.: Hybrid energy systems. Springer International Publishing, Cham 2018.

[33] www.energystoragesense.com/superconducting-magnetic-energy-storage-smes/ [05.10.2018].

[34] www.pgeeo.pl/Nasze-obiekty/Elektrownie-wodne/Zarnowiec. [05.10.2018].

[35] www.sierraclub.org/sierra/2015-5-september-october/innovate/how-storerenewable-energy-later\#2 [05.10.2018]

\section{M.Sc. Eng. Aleksander Chudy}

e-mail: aleksander.chudy@pollub.edu.pl

$\mathrm{He}$ is graduated from Lublin University of Technology in 2018. He obtained a bachelor's degree in 2017 and master's degree in 2018 in the field of electrical engineering. In the same year he started his Ph.D. studies at Lublin University of Technology in the field of electrical engineering. He is interested in electrical energy storage, nuclear energy and renewable energy.

ORCID ID: 0000-0002-3183-8450

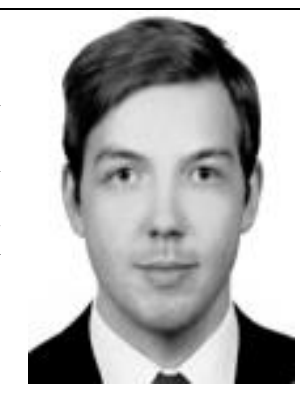

otrzymano/received: 27.10 .2018 